\title{
Nitrogen Removal Characteristics and Comparison of the Microbial Community Structure in Different Anaerobic Ammonia Oxidation Reactors
}

\author{
Liqiu Zhang ${ }^{1,2}{ }^{\oplus}$, Wei $\mathrm{Lv}^{1}$, Shugeng $\mathrm{Li}^{2,3, *}$, Zhongxuan Geng ${ }^{1}$ and Hainan Yao ${ }^{1}$ \\ 1 School of Civil Engineering, Guangzhou University, Guangzhou, 510006, China; zlqiu@gzhu.edu.cn (L.Z.); \\ 13826009294@163.com (W.L.); 18819480584@163.com (Z.G.); 2111716252@e.gzhu.edu.cn (H.Y.) \\ 2 Key Laboratory for Water Quality and Conservation of the Pearl River Delta, Ministry of Education, \\ Guangzhou University, Guangzhou 510006, China \\ 3 School of Environmental Science and Engineering, Guangzhou University, Guangzhou 510006, China \\ * Correspondence: lishugeng@gzhu.edu.cn
}

Received: 21 December 2018; Accepted: 26 January 2019; Published: 29 January 2019

\begin{abstract}
Nitrogen removal characteristics and the comparison of the microbial community structure were investigated in different anaerobic ammonia oxidation (Anammox) reactors: an anaerobic sequencing batch reactor (ASBR) and a biofilter reactor. The Anammox systems were inoculated with sludge from the second settling tank of a wastewater treatment plant in Guangzhou, China. After successful start up of Anammox, the microbial community structure of different Anammox reactors were studied through high-throughput sequencing. The results showed that anaerobic ammonium oxidation in the ASBR reactor could successfully start up after 134 days, while Anammox in the biofilter could start up after 114 days. In both systems, total nitrogen removal was at $80 \%$ after more than 200 days of operation. The diversity of denitrifying microorganisms was high in both reactors, with Planctomycetes as the main taxa. Anammox bacteria belonging to the genera Candidatus Anammoxoglobus and Kuenenia, were dominant in the ASBR, while all three genera of Candidatus, Anammoxoglobus, Kuenenia, and Brocadia, could be detected in the biofilter reactor. Therefore, the biofilter starts up faster than the ASBR, and contains richer species, which makes it more suitable to domesticate Anammox bacteria.
\end{abstract}

Keywords: Anammox; ASBR; biofilter; high-throughput sequencing

\section{Introduction}

Anaerobic ammonium oxidation (Anammox) was discovered and named in 1995 by researchers of the Delft University of Technology, Netherlands [1]. It is an alternative nitrogen removal process oxidizing $\mathrm{NH}_{4}{ }^{+}-\mathrm{N}$ into nitrogen, using $\mathrm{NO}_{2}^{-}-\mathrm{N}$ as an electron acceptor. The reaction equation was shown as follows:

$$
\begin{aligned}
\mathrm{NH}_{4}^{+}+1.32 \mathrm{NO}_{2}^{-} & +0.066 \mathrm{HCO}_{3}^{-}+0.13 \mathrm{H}^{+} \\
& \rightarrow 1.02 \mathrm{~N}_{2}+0.26 \mathrm{NO}_{3}^{-}+0.066 \mathrm{CH}_{2} \mathrm{O}_{0.5} \mathrm{~N}_{0.15}+2.03 \mathrm{H}_{2} \mathrm{O}
\end{aligned}
$$

The bacteria involved in this process, Anammox bacteria, are anaerobic autotrophic bacteria, and therefore Anammox is an anaerobic process and does not require an additional carbon source [2]. In this sense, it has been recognized as the most cost effective biological nitrogen removal approach. However, Anammox bacteria have a long doubling time, resulting in long start up periods for batch reactors and difficulties in enrichment, which severely limits large-scale applications.

Therefore, the selection of a suitable reactor for anaerobic ammonia oxidation plays an important role in the enrichment of Anammox bacteria. At present, most studies on Anammox oxidation have 
focused on three aspects: the rapid start up of Anammox reactors under different conditions [3-5], the factors potentially influencing Anammox bacteria [6,7], and the combined process of Anammox and other nitrogen removal processes [8-11]. All of these studies involved two types of reactors, an anaerobic sequencing batch reactor (ASBR) and a biofilter reactor [12]. They were assumed to be suitable reactors to enrich Anammox bacteria as ASBR could hold Anammox bacteria in its ideal sludge state [13] and the biofilter could prevent the loss of microorganisms due to its filter [14]. However, each study was only carried out using one type of reactor, and very few studies have been reported on the comparison of the two reactors during the start up of the Anammox process. Much attention has been given to the comparison of different seeding sludge sources $[15,16]$. Whether, with same seeding sludge source, the type of reactor influences results, and which type of reactor is more suitable for Anammox, are worth investigation.

At present, six genera of Anammox bacteria have been described, namely Brocadia, Kuenenia, Jettenia, Anammoxoglobus, Scalindua, and Anammoximicrobium [17]. Of these bacteria, Scalindua was found in seawater, while the other genera occur in various sewage systems [18]. In the early days, polymerase chain reaction (PCR) was used to detect Anammox bacteria [19]. Due to the limitations of conventional PCR, high-throughput sequencing has emerged with a number of advantages such as high accuracy, high speed and sensitivity, and it is highly automated [20]. It is, therefore, increasingly being used to detect bacterial species in various environments, especially in activated sludge systems, and it is also an effective tool to indicate the transformation of functional bacteria in the system, explaining the nitric-nitrogen effect in the system from the perspective of molecular biology.

In this study, two different reactor types, namely an ASBR reactor and a biofilter reactor, were used to start up anaerobic ammonia oxidation. High-throughput sequencing technology was used to characterize the microbial community structure in the two systems. The overall aims of this study were: 1) to obtain a more suitable reactor to start up Anammox oxidation; 2) to reveal any potential shifts in the microbial community from seeding sludge to enriched sludge; and 3) to determine the dominant bacteria in different reactors.

\section{Materials and Methods}

\subsection{Reactor Configuration}

The experiments were conducted in an ASBR reactor and a biofilter made of plexiglass with a working volume of $4.0 \mathrm{~L}$. Both reactors were operated at ambient temperature (the range was between 20 to $26^{\circ} \mathrm{C}$ ). The ASBR was equipped with a mechanical mixer operated constantly at $60 \mathrm{rpm}$ for mixing, while the biofilter reactor was equipped with a pump for an upward flow to continuously supply the substrate. Both reactors were covered with a black plastic bag to block out the light [21].

\subsection{Operational Strategies}

The two reactors were initially seeded with sludge obtained from the second settling tank of a wastewater treatment plant in Guangzhou, China. The ASBR reactor was operated on a $12 \mathrm{~h}$ cycle, consisting of five phases: $3 \mathrm{~min}$ filling, $10 \mathrm{~h}$ of anaerobic reaction, $0.5 \mathrm{~h}$ settling, $3 \mathrm{~min}$ of discharging $2.0 \mathrm{~L}$ of effluent, and $1.5 \mathrm{~h}$ idle. Two cycles were conducted per day and the hydraulic retention time (HRT) of ASBR was $24 \mathrm{~h}$. For the biofilter, the initial HRT was $24 \mathrm{~h}$; in both reactors, the $\mathrm{pH}$ of the influent was $7.5 \pm 0.1$.

The synthetic wastewater used consisted of $\mathrm{NH}_{4} \mathrm{Cl}, \mathrm{NaNO}_{2}$, and medium solution; $\mathrm{NH}_{4} \mathrm{Cl}$ and $\mathrm{NaNO}_{2}$ were dosed in the feeding medium to provide $\mathrm{NH}_{4}{ }^{+}-\mathrm{N}$ and $\mathrm{NO}_{2}^{-}-\mathrm{N}$. The medium solution contained the following nutrients: $\mathrm{NaHCO}_{3}$ at $0.2 \mathrm{~g} \cdot \mathrm{L}^{-1}, \mathrm{KH}_{2} \mathrm{PO}_{4}$ at $0.068 \mathrm{~g} \cdot \mathrm{L}^{-1}$, and $10 \mathrm{~mL}$ of each trace element solution I, II, and III. The compositions of trace element solution I, II, and III are shown in Table 1 . The $\mathrm{pH}$ was maintained at $7.5 \pm 0.1$ at the beginning of each cycle by adding sulfuric acid solution $(1 \mathrm{M})$ or sodium hydroxide solution $(1 \mathrm{M})$. 
Table 1. The compositions of trace element solution I, II, and III.

\begin{tabular}{ccc}
\hline Trace element solution & Reagent & Concentration \\
\hline \multirow{2}{*}{ I } & $\mathrm{FeSO}_{4} \cdot 7 \mathrm{H}_{2} \mathrm{O}$ & $45 \mathrm{~g} \cdot \mathrm{L}^{-1}$ \\
& $\mathrm{EDTA}$ & $25 \mathrm{~g} \cdot \mathrm{L}^{-1}$ \\
\hline \multirow{3}{*}{$\mathrm{II}$} & $\mathrm{KCl}$ & $3.5 \mathrm{~g} \cdot \mathrm{L}^{-1}$ \\
& $\mathrm{NaCl}$ & $2.5 \mathrm{~g} \cdot \mathrm{L}^{-1}$ \\
& $\mathrm{CaCl}_{2} \cdot 2 \mathrm{H}_{2} \mathrm{O}$ & $3.5 \mathrm{~g} \cdot \mathrm{L}^{-1}$ \\
$\mathrm{MgSO}_{4} \cdot 7 \mathrm{H}_{2} \mathrm{O}$ & $2.5 \mathrm{~g} \cdot \mathrm{L}^{-1}$ \\
\hline & $\mathrm{EDTA}$ & $75 \mathrm{~g} \cdot \mathrm{L}^{-1}$ \\
& $\mathrm{ZnSO}_{4} \cdot 7 \mathrm{H}_{2} \mathrm{O}$ & $2.15 \mathrm{~g} \cdot \mathrm{L}^{-1}$ \\
& $\mathrm{CoCl}_{2} \cdot 6 \mathrm{H}_{2} \mathrm{O}$ & $1.2 \mathrm{~g} \cdot \mathrm{L}^{-1}$ \\
& $\mathrm{MnCl}_{2} \cdot 4 \mathrm{H}_{2} \mathrm{O}$ & $4.95 \mathrm{~g} \cdot \mathrm{L}^{-1}$ \\
& $\mathrm{CuSO}_{4} \cdot 5 \mathrm{H}_{2} \mathrm{O}$ & $1.25 \mathrm{~g} \cdot \mathrm{L}^{-1}$ \\
& $\mathrm{Na}_{2} \mathrm{MoO}_{4} \cdot 2 \mathrm{H}_{2} \mathrm{O}$ & $1.1 \mathrm{~g} \cdot \mathrm{L}^{-1}$ \\
$\mathrm{NII}$ & $\mathrm{NiCl}_{2} \cdot 6 \mathrm{H}_{2} \mathrm{O}$ & $0.95 \mathrm{~g} \cdot \mathrm{L}^{-1}$ \\
& $\mathrm{Na}_{2} \mathrm{SeO}_{4} \cdot 10 \mathrm{H}_{2} \mathrm{O}$ & $1.05 \mathrm{~g} \cdot \mathrm{L}^{-1}$ \\
& $\mathrm{H}_{3} \mathrm{PO}_{4}$ & $0.07 \mathrm{~g} \cdot \mathrm{L}^{-1}$ \\
\hline
\end{tabular}

\subsection{Sample Collection, DNA Extraction, and High-Throughput Sequencing}

Biomass samples from the two reactors were collected after 240 days of operation to characterize the microbial community structure via high-throughput sequencing. The obtained mixed liquid sludge samples were filtered through filter paper $(11 \mathrm{~cm}, 45 \mathrm{um})$ and weighed $0.20-0.25 \mathrm{~g}$ for DNA extraction. Genomic DNA was extracted by the Power Soil DNA Isolation Kit (Mobio, USA) and diluted to $10 \mathrm{ng} / \mu \mathrm{L}$ for subsequent analysis.

Nested polymerase chain reaction, amplifying the V3-V4 region of the 16S rRNA gene, was conducted using the bacterial universal primers 341F (5'-CCCTACACGACGCTCTTCCGATCTG-3') and 805R (5'-GACTGGAGTTCCTTGGCACCCGAGAATTCCA-3'). For the amplification of each sample, we added $15 \mu \mathrm{L}$ of $2 \times$ Taq master mix, $1 \mu \mathrm{L}$ of Bar-PCR primer $\mathrm{F}(10 \mu \mathrm{M}), 1 \mu \mathrm{L}$ of primer $\mathrm{R}(10 \mu \mathrm{M}), 10-20 \mathrm{ng}$ of template DNA, and brought the solution up to $30 \mu \mathrm{L}$ with $\mathrm{ddH}_{2} \mathrm{O}$. The PCR program consisted of an initial denaturation step at $94{ }^{\circ} \mathrm{C}$ for $3 \mathrm{~min}$, followed by five cycles at $94{ }^{\circ} \mathrm{C}$ for $30 \mathrm{~s}, 45^{\circ} \mathrm{C}$ for $20 \mathrm{~s}$, and $65^{\circ} \mathrm{C}$ for $30 \mathrm{~s}$, followed by another 20 cycles at $94{ }^{\circ} \mathrm{C}$ for $20 \mathrm{~s}, 55^{\circ} \mathrm{C}$ for $20 \mathrm{~s}$, and $72{ }^{\circ} \mathrm{C}$ for $30 \mathrm{~s}$, and a final extension step at $72{ }^{\circ} \mathrm{C}$ for $10 \mathrm{~min}$. During the second amplification, we added $15 \mu \mathrm{L}$ of $2 \times$ Taq master mix, $1 \mu \mathrm{L}$ of Bar-PCR primer $\mathrm{F}(10 \mu \mathrm{M}), 1 \mu \mathrm{L}$ of Primer $\mathrm{R}(10 \mu \mathrm{M}), 20 \mathrm{ng}$ of the PCR product from the first step, and brought the solution up to $30 \mu \mathrm{L}$ with $\mathrm{ddH}_{2} \mathrm{O}$. The $\mathrm{PCR}$ program consisted of an initial denaturation step at $95^{\circ} \mathrm{C}$ for $3 \mathrm{~min}$, followed by five cycles at $94{ }^{\circ} \mathrm{C}$ for $20 \mathrm{~s}, 55^{\circ} \mathrm{C}$ for $20 \mathrm{~s}$, and $72{ }^{\circ} \mathrm{C}$ for $30 \mathrm{~s}$, and a final extension step at $72{ }^{\circ} \mathrm{C}$ for $5 \mathrm{~min}$. The DNA-amplified samples were sequenced using an Illumina MiSeq sequencer (ID: PRJNA505712).

\subsection{Analytical Methods}

Effluent samples were collected daily into a $25 \mathrm{~mL}$ sampling cup and then filtered through $45 \mu \mathrm{m}$ filters. Each sample was immediately stored at $4{ }^{\circ} \mathrm{C}$ and analyzed on the following day for ammonium nitrogen $\left(\mathrm{NH}_{4}{ }^{+}-\mathrm{N}\right)$, nitrite nitrogen $\left(\mathrm{NO}_{2}{ }^{-}-\mathrm{N}\right)$, and nitrate nitrogen $\left(\mathrm{NO}_{3}{ }^{-}-\mathrm{N}\right)$, using Nessler's reagent spectrophotometry, $\mathrm{N}$-(1-naphthyl)-ethylenediamine reagent spectrophotometry, and Thymol reagent spectrophotometry, respectively, with a UV spectrophotometer (UV-2550, SHIMADZU, Japan). The concentration of total nitrogen (TN) in the influent and the effluent equaled the sum of $\mathrm{NH}_{4}{ }^{+}-\mathrm{N}$, $\mathrm{NO}_{2}{ }^{-}-\mathrm{N}$, and $\mathrm{NO}_{3}{ }^{-}-\mathrm{N}$. Dissolved oxygen (DO) and $\mathrm{pH}$ were determined using oxygen and $\mathrm{pH}$ probes, respectively (WTW pH/Oxi 340i, WTW Company, Germany). 


\section{Results and Discussion}

\subsection{Nitrogen Removal at Different Stages}

\subsubsection{ASBR Reactor}

The ASBR reactor was operated over 246 days, with a start up period of 134 days. After the start up period, influent TN was steadily increased. Microbial endogenous respiration leads to cell decay and lysis when substrate is depleted [22], therefore, increasing substrate concentration in influent over time is necessary. Based on the different conditions during the operational period, the process was divided into seven phases, as shown in Table 2. The concentration of effluent TN, TN removal efficiency, and the stoichiometric ratio in the ASBR over the whole operation time are shown in Figure 1. It should be noted that theoretical values of the nitrite removal/ammonium removal ratio and the nitrate accumulation/ammonium removal ratio were 1.32 and 0.26 , respectively, based on equation 1 from the introduction.

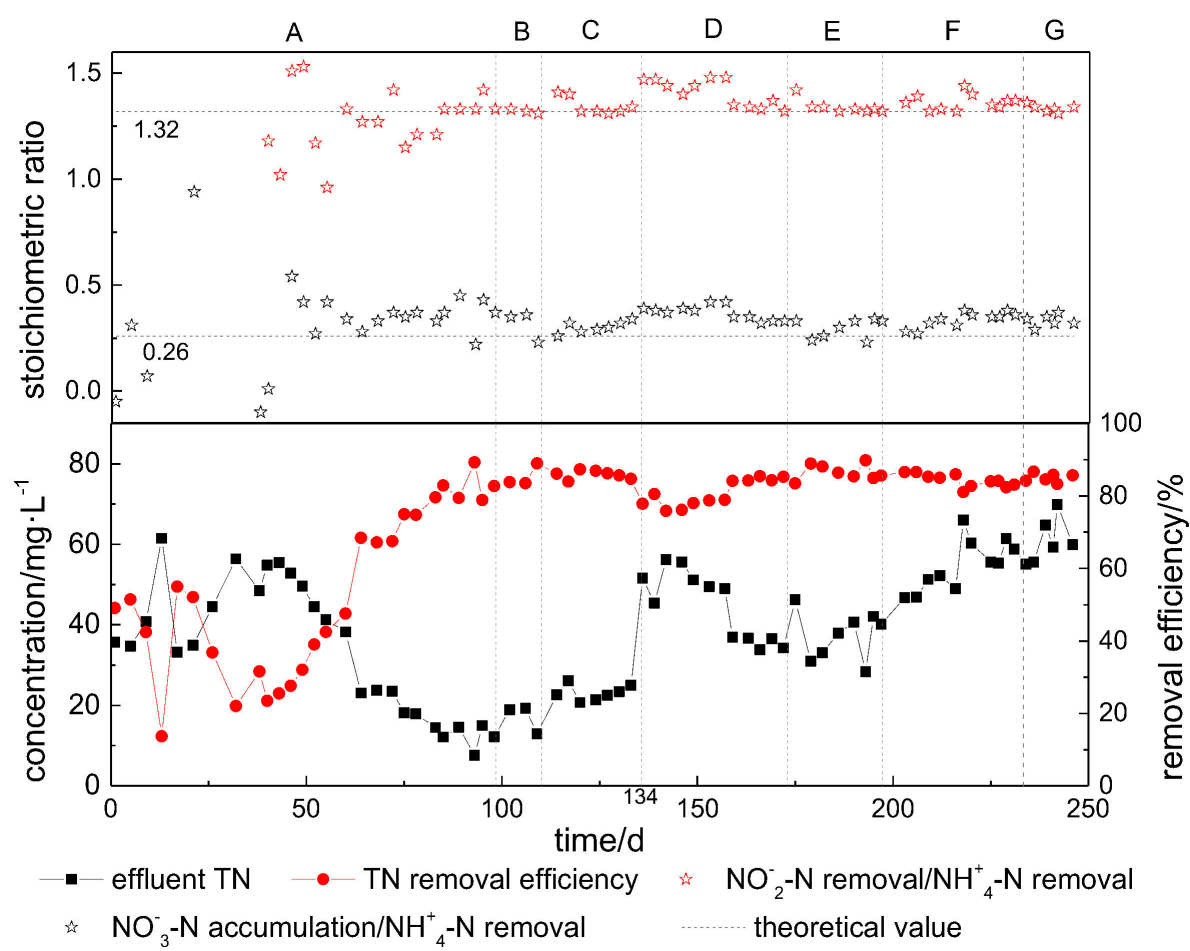

Figure 1. Total nitrogen (TN) concentration of effluent, TN removal efficiency, and stoichiometric ratios in an anaerobic sequencing batch reactor (ASBR) over the whole operation time.

Table 2. Total nitrogen concentration of the ASBR at different stages (phase A to G).

\begin{tabular}{cccccccc}
\hline & A & B & C & D & E & F & G \\
\hline Time $/ \mathrm{d}$ & $1-98$ & $99-109$ & $110-134$ & $135-172$ & $173-197$ & $198-234$ & $235-246$ \\
$\mathrm{TN} / \mathrm{mg} \cdot \mathrm{L}^{-1}$ & 72.28 & 116.96 & 163.36 & 232.96 & 279.36 & 348.96 & 418.56 \\
\hline
\end{tabular}

During phase A (days 1-98), the average influent TN stabilized at $72.28 \mathrm{mg} \cdot \mathrm{L}^{-1}$. Over time, with microbial endogenous respiration, the concentration of TN in the effluent gradually decreased, and TN removal efficiency increased and reached $89.25 \%$. Because of the presence of Anammox bacteria in the system, the concentration of TN in the effluent did not reach zero. As the nitrite removal/ammonium removal ratio was close to the theoretical value, it was assumed that Anammox bacteria were present, but were not the dominant bacteria. To increase the activity of Anammox and avoid the Anammox microbial endogenous respiration caused by long periods of anoxic stirring after 
substrate depletion, substrate concentration in influent was gradually increased from $116.96 \mathrm{mg} \cdot \mathrm{L}^{-1}$ to $418.56 \mathrm{mg} \cdot \mathrm{L}^{-1}$. At the same time, the nitrate accumulation/ammonium removal ratio was getting closer to the theoretical value. The ratio between average ammonium removal, nitrite removal, and nitrate accumulation was 1:1.36:0.33. After the start up period, influent TN was steadily increased to improve microbial activity. The ASBR reactor could successfully start and maintain Anammox, with a TN removal efficiency above $80 \%$ after more than 200 days of operation. TN removal efficiency would decrease a short time after TN concentration increased at the start of each stage, and after operating for some time, it would recover to as high of an efficiency as before. During the whole start up the stoichiometric ratio was higher than the theoretical value, which means there were a variety of types of bacteria, and that they worked together to remove TN from the ASBR system.

\subsubsection{Biofilter Reactor}

The biofilter reactor was operated for 246 days, with a start up period of 114 days. Figure 2 shows the concentration of TN, TN removal efficiency, and the stoichiometric ratio in the biofilter reactor during the operating time. Based on the different operational conditions, the process was divided into 11 phases.

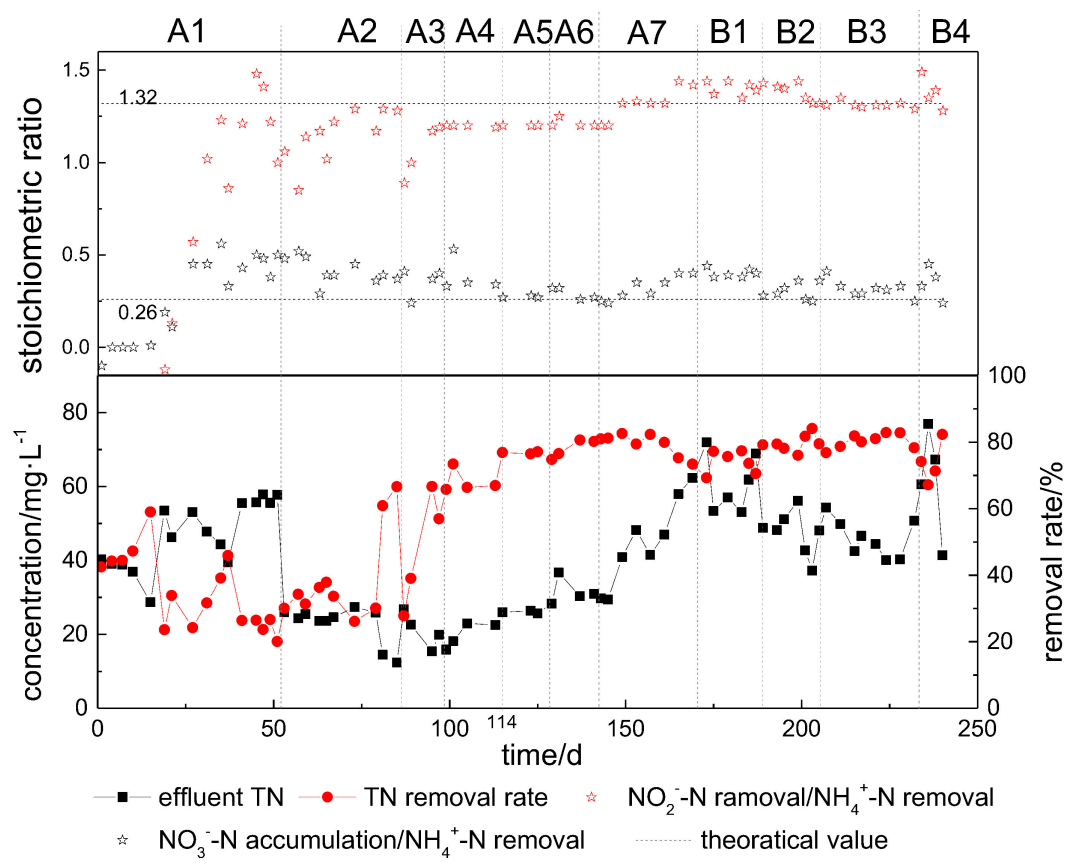

Figure 2. Total nitrogen (TN) concentration of effluent, TN removal efficiency, and stoichiometric ratios in the biofilter over the whole operation time.

The TN concentrations of influent and HRT values of the different phases are shown in Table 3. The values of TN gradually increased from A1 to A7; because of the gradual adaptation of the bacteria to the operational conditions and the increased biomass activity, the HRT decreased from $24 \mathrm{~h}$ to $8 \mathrm{~h}$ during phases B1 to B4.

Table 3. Influent TN concentration and hydraulic retention time (HRT) of each stage of the biological filter reactor.

\begin{tabular}{cccccccccccc}
\hline & A1 & A2 & A3 & A4 & A5 & A6 & A7 & B1 & B2 & B3 & B4 \\
\hline Time/d & $1-51$ & $52-89$ & $90-99$ & $100-114$ & $115-129$ & $130-145$ & $150-169$ & $170-187$ & $188-205$ & $206-228$ & $229-240$ \\
TN/mg.L -1 & 70 & 37.08 & 46.28 & 70 & 112.28 & 156.28 & 234.28 & 234.28 & 234.28 & 234.28 & 234.28 \\
HRT/h & 24 & 24 & 24 & 24 & 24 & 24 & 24 & 20 & 16 & 12 & 8 \\
\hline
\end{tabular}

Note: The error of total nitrogen concentration in influent water at each stage was controlled within \pm 1.00 . 
The start up phase of the biofilter reactor lasted for 114 days, from phase A1 to phase A4. In phase A1, the nitrite removal/ammonium removal ratio was lower than the theoretical value which was below 1.32, while the nitrate accumulation/ammonium removal ratio was higher than 0.26 , and even reached 0.59. The results also showed that the removal efficiency of $\mathrm{NO}_{2}{ }^{-}-\mathrm{N}$ was higher than that of $\mathrm{NH}_{4}{ }^{+}-\mathrm{N}$ together with a high accumulation of $\mathrm{NO}_{3}{ }^{-}-\mathrm{N}$, which resulted in a gradual increase in the concentration of effluent TN. As seen in Figure 2, at this phase, the TN in the effluent had accumulated significantly, up to $59.06 \mathrm{mg} \cdot \mathrm{L}^{-1}$, and the TN removal efficiency was below $42.3 \%$. These results also indicated that Anammox bacteria were not the dominant bacteria in the system and that nitrite-oxidizing bacteria (NOB) and denitrifying bacteria were more concentrated than the Anammox bacteria at that time. Previous studies have shown that this type of reactor could be operated stably when the substrate ratio was less than 1:1.62 [23]. Therefore, the concentration ratio of influent $\mathrm{NO}_{2}{ }^{-}-\mathrm{N}$ and $\mathrm{NH}_{4}{ }^{+}-\mathrm{N}$ was reduced to 1.2 in order to induce growth of Anammox bacteria into the dominant taxa. At phase $\mathrm{A} 2$, the nitrite removal/ammonium removal ratio increased gradually from 0.94 to 1.31 , while the nitrate accumulation/ammonium removal ratio decreased gradually from 0.51 to 0.31 . The maximum TN removal efficiency was $60 \%$. After 94 days of operation (at the end of phase A6), the concentration ratio of influent $\mathrm{NO}_{2}{ }^{-}-\mathrm{N}$ and $\mathrm{NH}_{4}{ }^{+}-\mathrm{N}$ was recovered to 1.32 with high $\mathrm{TN}$ removal efficiency.

It should be noted that after more than 100 days of operation, at the end of phase A4, the TN removal efficiency was stable, and the stoichiometric ratio tended to be close to the theoretical value (due to the adjustment of the ratio of influent, the ratio of $\mathrm{NO}_{2}{ }^{-}-\mathrm{N}$ removal $/ \mathrm{NH}_{4}{ }^{+}-\mathrm{N}$ removal tends towards 1.2 rather than 1.32). This showed that Anammox bacteria gradually became the dominant species in the system, indicating a successful start up phase.

Subsequently, to further increase the activity of Anammox bacteria, the influent TN was gradually increased to $234.28 \pm 1.00 \mathrm{mg} \cdot \mathrm{L}^{-1}$. After 169 days of operation, the removal efficiency of TN reached $82.56 \%$. An efficient way to increase TN load was shortening the HRT [24]. Considering that the HRT of the biofilter reactor could be controlled by adjusting the flow rate, it was shortened from $24 \mathrm{~h}$ to $8 \mathrm{~h}$ from phase B1 to B4. The nitrite removal/ammonium removal ratio fluctuated close to the theoretical value, while the nitrate accumulation/ammonium removal ratio was higher than the theoretical value. The ratio between average ammonium removal, nitrite removal, and nitrate accumulation was 1:1.33:0.32. Therefore, it was assumed that other denitrifying bacteria were still present in the system. The nitrite removal/ammonium removal ratio largely deviated after 230 days, and after adjusting the influent $\mathrm{pH}$ in the later stage, the system gradually returned to normal.

The results showed that biofilter reactors could also be used to acclimate and enrich Anammox bacteria. Anammox bacteria could be enriched more rapidly in biofilter reactors than in an ASBR. In addition, the TN load could be increased indirectly by shortening the HRT in a biofilter. After more than 200 days of operation, TN removal efficiency in the biofilter stabilized at more than $80 \%$.

\subsection{Microbial Community Analysis in Different Systems}

\subsubsection{Microbial Community Richness and Alpha Diversity}

Three 16S rRNA gene libraries were constructed via Illumina MiSeq sequencing of the seed sludge (sample a), the ASBR (sample b), and the biofilter (sample c) community, with 41,708, 52,976, and 63,983 high-quality reads, respectively. All indexes are shown in Table 4.

Table 4. Microbial community richness and alpha diversity in seed sludge (a), domesticated sludge of the ASBR reactor (b), and domesticated sludge of the biofilter (c).

\begin{tabular}{cccc}
\hline Estimator index & $\mathbf{a}$ & $\mathbf{b}$ & $\mathbf{c}$ \\
\hline ACE index & $107,031.0$ & $267,200.6$ & $420,401.1$ \\
Chao index & $47,726.38$ & $88,476.66$ & $138,852.20$ \\
Shannon index & 6.75 & 5.10 & 5.18 \\
Simpson index & $6.3 \times 10^{-3}$. & 0.04 & 0.06 \\
Coverage index & 0.86 & 0.86 & 0.84 \\
\hline
\end{tabular}


The value of the Shannon diversity index indicates the abundance of species within a community; larger values indicate a higher phyla diversity. Among the three investigated samples, seed sludge had the highest diversity (Shannon index $=6.75$ ), while the ASBR and the biofilter reactor had values of 5.10 and 5.18 , respectively.

The results showed that the seed sludge from the secondary sedimentation tank of the wastewater treatment plant contained more bacterial species, and after cultivation and acclimation to a special environment, the activated sludge in the reactor was gradually being replaced and enriched, resulting in a decreased diversity. Based on this, it could be inferred that the microbial community structures were affected by the different reactor features, and different bacterial groups were enriched in both the ASBR and the biofilter reactor.

\subsubsection{Changes in Microbial Community Structure During Operation}

The similarities and differences among the three systems were identified using hierarchical cluster analysis shown in Figure 3. Some strains in the seed sludge clearly differed from those in the ASBR and the biofilter, for example the color of Planctomycetes in the ASBR and the biofilter seemed relatively red, which means that after long-term domestication, Planctomycetes gradually become the dominant group and was successfully enriched in both reactors.

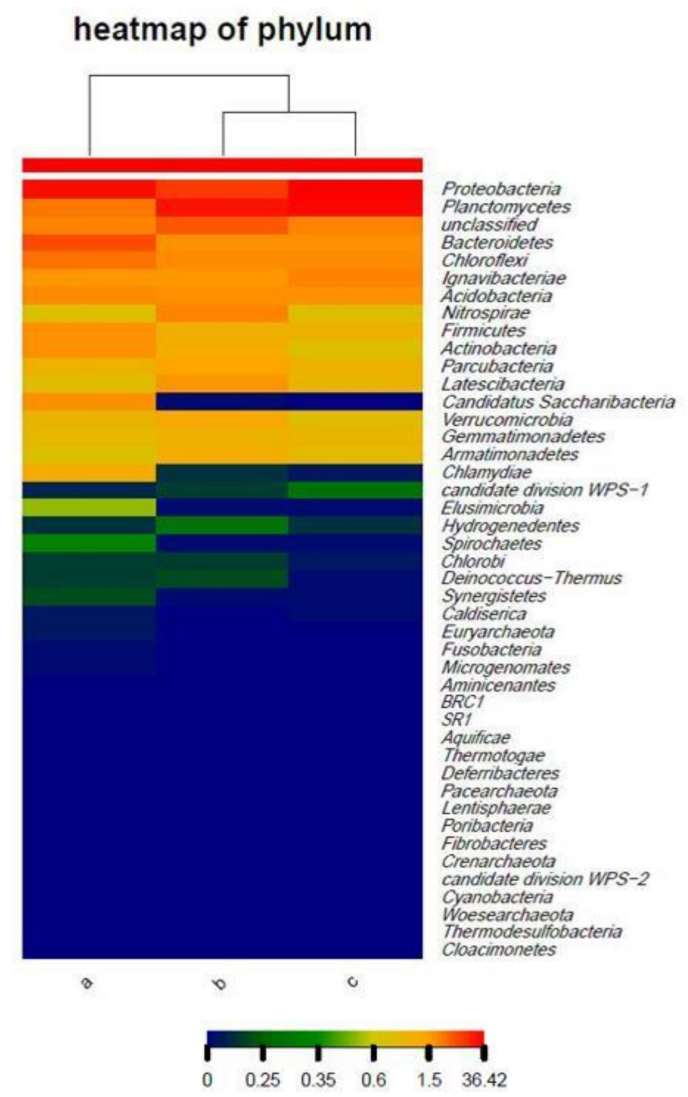

Figure 3. Heatmap of $16 \mathrm{~S}$ rRNA metagenomics of the microbial populations of $a, b$, and c samples. Samples $a, b$, and c were for seed sludge, ASBR sludge, and biofilter reactor sludge, respectively. Color scale from blue (lowest abundance) to red (highest abundance).

In the three samples, 44 phyla were detected, of which eight were present in all three samples; the phyla involved in nitrogen removal were Proteobacteria, Planctomycetes, and Nitrospirae. The proportions of Proteobacteria, Planctomycetes, and Nitrospirae in the different samples are summarized in Table 5. After enrichment in the reactors, the Planctomycetes increased in both reactors to become $31.08 \%$ of all bacteria in the ASBR and $33.79 \%$ in the biofilter. 
Table 5. The percentages of Proteobacteria, Planctomycetes, and Nitrospirae in seed sludge (a), domesticated sludge of the ASBR reactor (b), and domesticated sludge of the biofilter (c).

\begin{tabular}{cccc}
\hline & Sample a & Sample b & Sample c \\
\hline Proteobacteria & $33.46 \%$ & $23.72 \%$ & $36.42 \%$ \\
Planctomycetes & $9.7 \%$ & $31.08 \%$ & $33.79 \%$ \\
Nitrospirae & $0.37 \%$ & $6.91 \%$ & $0.39 \%$ \\
\hline
\end{tabular}

Numerous bacterial populations are involved in nitrification, denitrification, and Anammox processes. Figure 4 illustrates the phyla abundance of bacterial communities in the seed sludge, the ASBR sludge, and the biofilter sludge. Most bacteria belonged to the Proteobacteria and the Planctomycetes, which accounted for over $50 \%$ of all bacteria in the ASBR and biofilter samples. According to these results, prolonged sludge domestication could make the target species gradually become the dominant one.

Ammonia oxidizing bacteria (AOB) and some NOB belong to the group Proteobacteria, while Anammox bacteria belong to Planctomycetes and other NOB belong to Nitrospirae. In the seed sludge, Planctomycetes only accounted for $9.7 \%$ of the population, but after long-term domestication, both reactors contained more Planctomycetes, indicating that Anammox bacteria were successfully enriched. The seed sludge contained a large amount of $A O B$, and after a relatively long domestication period, $\mathrm{AOB}$ were still abundant in the two reactors. So ammonium in the reactors could be removed through the cooperation of $\mathrm{AOB}$ and Anammox bacteria. Unlike the biofilter reactor, the ASBR contained a certain amount of Nitrospirae bacteria, which can convert $\mathrm{NO}_{2}^{-}-\mathrm{N}$ to $\mathrm{NO}_{3}{ }^{-}-\mathrm{N}$, and therefore, the concentration of $\mathrm{NO}_{3}{ }^{-}-\mathrm{N}$ in the effluent of the ASBR reactor was slightly higher than that in the biofilter reactor.

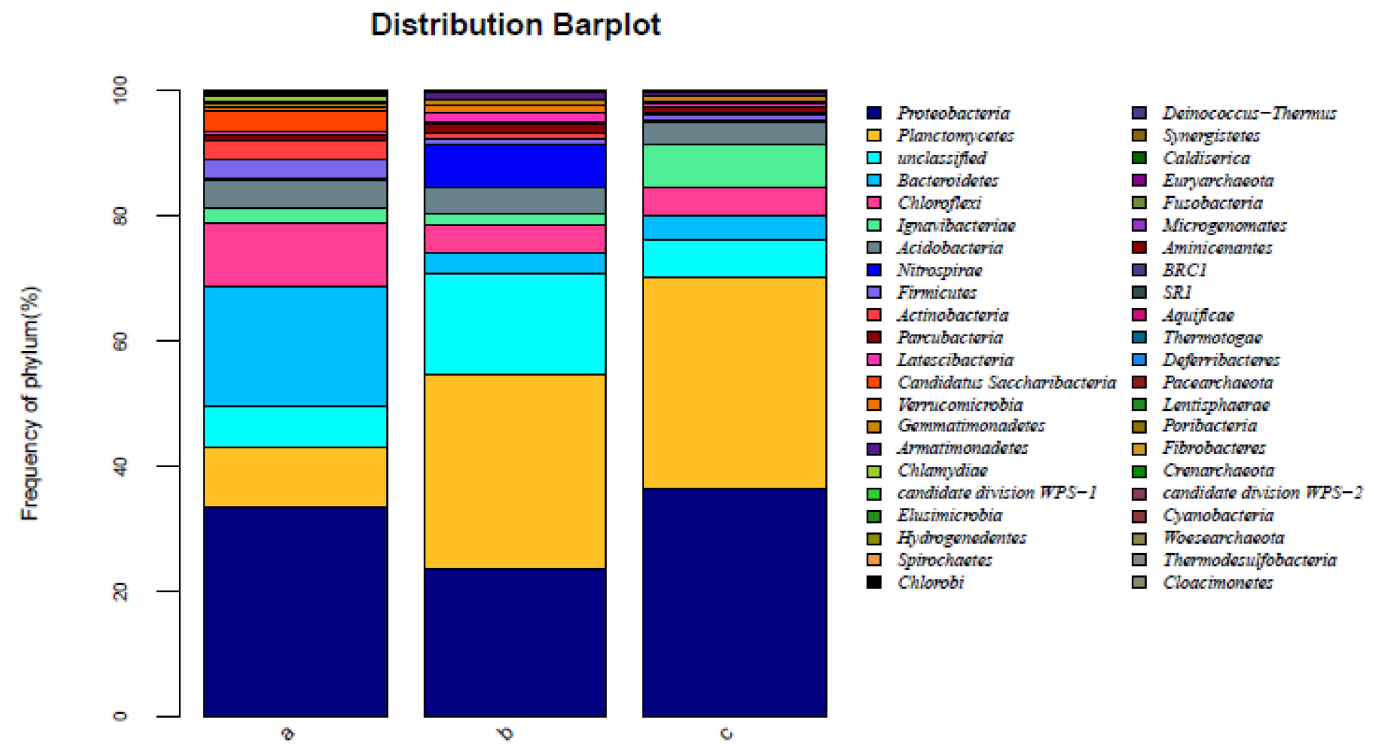

Figure 4. The phyla abundance of bacterial communities in a, b, and c samples. Samples a, b, and c were for seed sludge, ASBR sludge, and biofilter reactor sludge, respectively.

It was worth noting that the phylum Chloroflexi was present in each sample, and in previous studies it had often been observed in autotrophic nitrogen removal systems as it could effectively degrade and use dead biomass and prevent the accumulation of organic waste in the system [25].

The phylum involved with nitrogen removal was selected for further analysis at the genus level. The results are shown in Figure 5. 


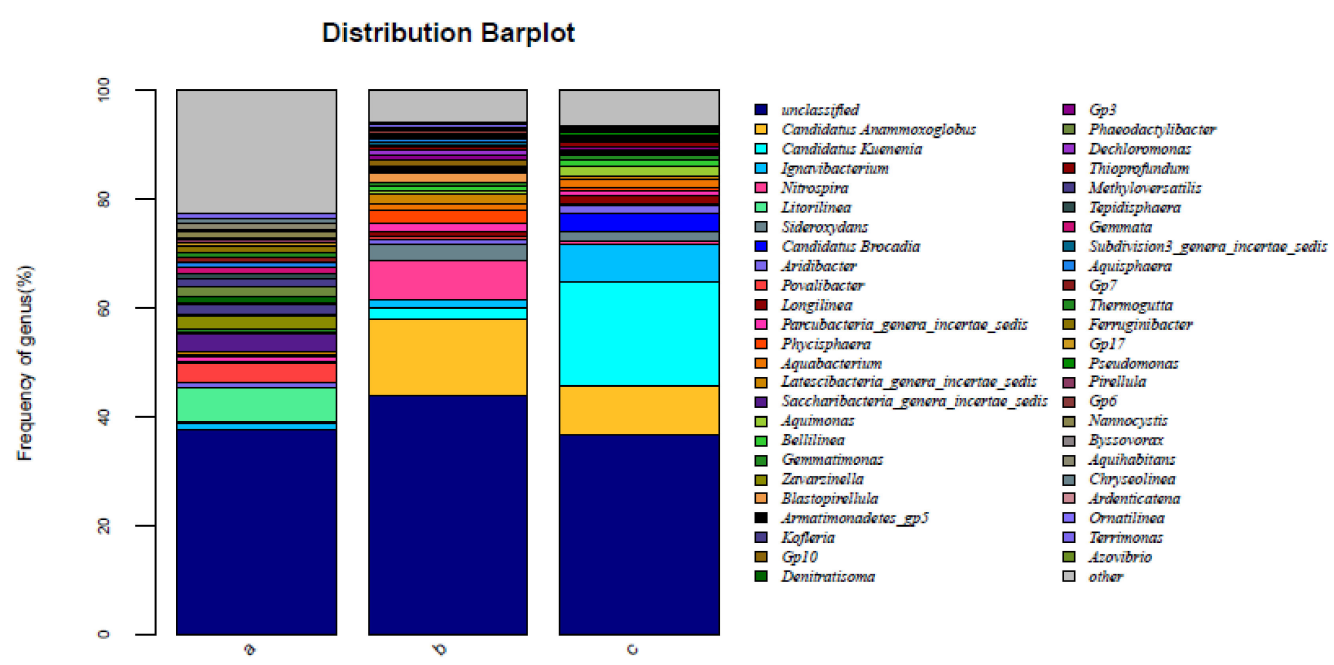

Figure 5. The genera abundance of bacterial communities in a, b, and c samples. Samples a, b, and c were for seed sludge, ASBR sludge, and biofilter reactor sludge, respectively.

Based on Figure 5, Candidatus Anammoxoglobus and Candidatus Kuenenia were mainly responsible for anaerobic ammonia oxidation in both the ASBR and the biofilter reactor. Candidatus Brocadia was of some importance in the biofilter reactor. In addition, Denitamisoma accounted for $0.27 \%$ of the bacteria in the biofilter reactor, and contributed to denitrification together with Anammox bacteria.

\section{Conclusions}

In this study, both the ASBR and the biofilter reactor could be used to start up Anammox processes. Stable nitrogen removal in both reactors was observed for more than 200 days, while high TN removal efficiencies were achieved $(>80 \%)$. The start up period of the biofilter $(114 \mathrm{~d})$ was shorter than that of the ASBR (134 d). After enrichment in the reactors, the main organisms contributing to anaerobic ammonia oxidation were Candidatus Anammoxoglobus and Candidatus Kuenenia existing in both reactors. In addition to the above two species, the biofilter reactor also contained a small amount of Candidatus Brocadia, indicating a higher biological diversity in this reactor. The ratio of nitrite removal/ammonium removal and nitrate accumulation/ammonium removal were all higher than the theoretical values, indicating that not only Anammox bacteria, but also AOB, NOB, and denitrifying microorganisms were in both reactor types. The biofilter not only started up faster than the ASBR, but contained richer species as well, which showed it is more suitable for the domestication of Anammox bacteria.

Author Contributions: L.Z. and W.L. conceived and designed the experiments; W.L. and H.Y. performed the experiments; W.L. and Z.G. analyzed the data; L.Z. and S.L. contributed reagents/materials/analysis tools; W.L., L.Z. and S.L. wrote the paper; L.Z. and S.L. revised the paper.

Funding: This study was funded by the National Natural Science Foundation of China (Grant No. 51478127, 51708140).

Acknowledgments: We are grateful to the anonymous reviewers for their useful comments and suggestions. Conflicts of Interest: The authors declare no conflict of interest.

\section{References}

1. Mulder, A.; Graaf, A.A.; Robertson, L.A.; Kuenen, J.G. Anaerobic ammonium oxidation discovered in a denitrifying fluidized bed reactor. FEMS Microbiol. Ecol. 1995, 16, 177-183. [CrossRef]

2. Zhu, W.; Zhang, P.; Dong, H.; Li, J. Effect of carbon source on nitrogen removal in anaerobic ammonium oxidation (anammox) process. J. Biosci. Bioeng. 2016, 123, 497-504. [CrossRef] [PubMed]

3. Zhao, R.; Zhang, H.; Zhang, F.; Yang, F. Fast start-up anammox process using Acyl-homoserine lactones (AHLs) containing supernatant. J. Environ. Sci. 2018, 65, 127-132. [CrossRef] [PubMed]

4. Bi, Z.; Qiao, S.; Zhou, J.; Tang, X.; Zhang, J. Fast start-up of Anammox process with appropriate ferrous iron concentration. Bioresour. Technol. 2014, 170, 506-512. [CrossRef] 
5. Yin, X.; Qiao, S.; Zhou, J.; Tang, X. Fast start-up of the anammox process with addition of reduced graphene oxides. Chem. Eng. J. 2016, 283, 160-166. [CrossRef]

6. Isanta, E.; Bezerra, T.; Fernández, I.; Suárez-Ojeda, M.E.; Pérez, J.; Carrera, J. Microbial community shifts on an anammox reactor after a temperature shock using 454-pyrosequencing analysis. Bioresour. Technol. 2015, 181, 207-213. [CrossRef] [PubMed]

7. Wang, G.; Zhang, D.; Xu, Y.; Hua, Y.; Dai, X. Comparing two start up strategies and the effect of temperature fluctuations on the performance of mainstream anammox reactors. Chemosphere 2018, 209, 632-639. [CrossRef]

8. Han, Y.; Liu, F.; Xu, X.; Yan, Z.; Liu, Z. Nitrogen removal via a single-stage PN-Anammox process in a novel combined biofilm reactor. Water Sci. Technol. 2018, 77, 1483-1492. [CrossRef]

9. Sri, S.S.; Joseph, K. Combined SHARON and ANAMMOX processes for ammoniacal nitrogen stabilisation in landfill bioreactors. Bioresour. Technol. 2017, 250, 723-732.

10. Waki, M.; Yasuda, T.; Suzuki, K.; Sakai, T.; Suzuki, N.; Suzuki, R.; Matsuba, K.; Yokoyama, H.; Ogino, A.; Tanaka, Y. Rate determination and distribution of anammox activity in activated sludge treating swine wastewater. Bioresour. Technol. 2010, 101, 2685-2690. [CrossRef]

11. Ding, S.; Bao, P.; Wang, B.; Zhang, Q.; Peng, Y. Long-term stable simultaneous partial nitrification, anammox and denitrification (SNAD) process treating real domestic sewage using suspended activated sludge. Chem. Eng. J. 2018, 339, 180-188. [CrossRef]

12. Jin, R.C.; Zheng, P.; Hu, A.H.; Mahmood, Q.; Hu, B.L.; Jilani, G. Performance comparison of two anammox reactors: sbr and ubf. Chem. Eng. J. 2008, 138, 224-230. [CrossRef]

13. Dapenacmora, A.; Arrojo, B.; Campos, J.L.; Mosqueraxorral, A.; Méndez, R. Improvement of the settling properties of anammox sludge in an sbr. J. Chem. Technol. Biotechnol. 2004, 79, 1417-1420. [CrossRef]

14. Furukawa, K.; Rouse, J.D.; Yoshida, N.; Hatanaka, H. Mass Cultivation of Anaerobic Ammonium-Oxidizing Sludge Using a Novel Nonwoven Biomass Carrier. J. Chem. Eng. Jpn. 2003, 36, 1163-1169. [CrossRef]

15. Date, Y.; Isaka, K.; Ikuta, H.; Sumino, T.; Kaneko, N.; Yoshie, S. Microbial diversity of anammox bacteria enriched from different types of seed sludge in an anaerobic continuous-feeding cultivation reactor. J. Biosci. Bioeng. 2009, 107, 281-286. [CrossRef] [PubMed]

16. Wang, T.; Zhang, H.M.; Gao, D.W.; Yang, F.L.; Yang, S.A.; Jiang, T. Enrichment of anammox bacteria in seed sludges from different wastewater treating processes and start-up of anammox process. Desalination 2011, 271, 193-198. [CrossRef]

17. Hu, Q.; Kang, D.; Wang, R.; Ding, A.; Abbas, G.; Zhang, M.; Qiu, L.; Lu, H.; Lu, H.; Zheng, P. Characterization of oligotrophic AnAOB culture: Morphological, physiological, and ecological features. Appl. Microbiol. Biotechnol. 2018, 102, 995-1003. [CrossRef] [PubMed]

18. Laura, V.; Speth, D.R.; Theo, V.A.; Alexander, H.; Jetten, M.S.M. Shotgun metagenomic data reveals significant abundance but low diversity of "CandidatusScalindua" marine anammox bacteria in the Arabian Sea oxygen minimum zone. Front. Microbiol. 2014, 5, 31.

19. Zhou, Z.; Chen, J.; Meng, H.; Dvornyk, V.; Gu, J. New PCR primers targeting hydrazine synthase and cytochrome c biogenesis proteins in anammox bacteria. Appl. Microbiol. Biotechnol. 2017, 101, 1-21. [CrossRef]

20. Park, H.; Murthy, S.; Bott, C.; Loosdrecht, M.C.M.V.; Chandran, K. Nationwide metagenome survey of anammox processes via high-throughput next generation sequencing (NGS): 2012-2013. Water Environ. Res. 2014, 600, 2366-2371. [CrossRef]

21. Babaei, A.A.; Azadi, R.; Jaafarzadeh, N.; Alavi, N. Application and kinetic evaluation of upflow anaerobic biofilm reactor for nitrogen removal from wastewater by Anammox process. Iran J. Environ. Health 2013, 10, 20. [CrossRef] [PubMed]

22. Du, R.; Cao, S.; Li, B.; Niu, M.; Wang, S.; Peng, Y. Performance and microbial community analysis of a novel DEAMOX based on partial-denitrification and anammox treating ammonia and nitrate wastewaters. Water Res. 2016, 108, 46-56. [CrossRef] [PubMed]

23. Jin, R.; Xing, B.; Yu, J.; Qin, T.; Chen, S. The importance of the substrate ratio in the operation of the Anammox process in upflow biofilter. Ecol. Eng. 2013, 53, 130-137. [CrossRef]

24. Zhang, Y.; Peng, Y.; Zeng, L.; Hu, S.; Cui, P.; Ma, J.; Chen, Y. Quick start-up of low-substrate Anammox ASBR reactor at normal temperature. Ind. Water Treat. 2017, 37, 43-47. (In Chinese) 
25. Kindaichi, T.; Yuri, S.; Ozaki, N.; Ohashi, A. Ecophysiological role and function of uncultured Chloroflexi in an anammox reactor. Water Sci. Technol. 2012, 66, 2556-2561. [CrossRef] [PubMed] 